This item was submitted to Loughborough's Research Repository by the author.

Items in Figshare are protected by copyright, with all rights reserved, unless otherwise indicated.

\title{
Performance-based optimization of land and water resources within irrigation
} schemes I: Method

PLEASE CITE THE PUBLISHED VERSION

PUBLISHER

(C) American Society of Civil Engineers

LICENCE

CC BY-NC-ND 4.0

REPOSITORY RECORD

Gorantiwar, S.D., Ian K. Smout, and Kalanithy Vairavamoorthy. 2019. "Performance-based Optimization of Land and Water Resources Within Irrigation Schemes I: Method". figshare. https://hdl.handle.net/2134/3661. 
This item was submitted to Loughborough's Institutional Repository by the author and is made available under the following Creative Commons Licence conditions.

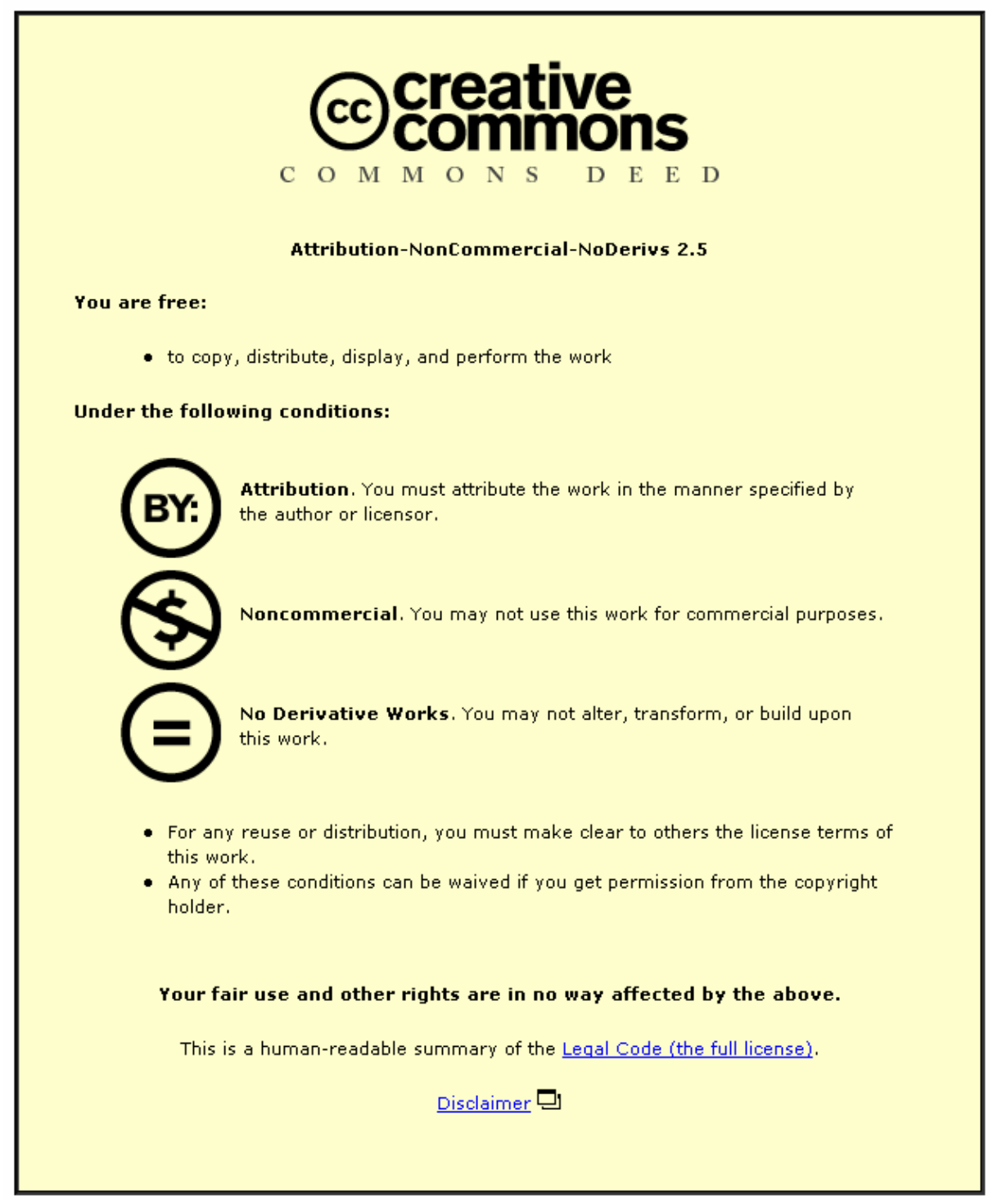

For the full text of this licence, please go to: http://creativecommons.org/licenses/by-nc-nd/2.5/ 


\title{
PERFORMANCE BASED OPTIMIZATION OF LAND AND WATER
}

\section{RESOURCES WITHIN IRRIGATION SCHEMES: 1. METHOD}

\section{Sunil D. Gorantiwar ${ }^{1}$, Ian K. Smout ${ }^{2}$ and K. Vairavamoorthy ${ }^{3}$}

\begin{abstract}
Optimum land and water allocation to different crops grown in different regions of an irrigation scheme is a complex process, especially when these irrigation schemes are characterized by different soils and environment and by a large network of canals. At the same time if the water supply in the irrigation schemes is limited, there is a need to allocate water both efficiently and equitably. This paper describes the approach to include both productivity (efficiency) and equity in the allocation process and to develop the allocation plans for optimum productivity and/or maximum equity for such irrigation schemes. The approach presented in this paper considers the different dimensions of equity such as water distribution over the season, water distribution during each irrigation, benefits generated. It also includes distribution and conveyance losses while allocating water equitably to different allocation units. This paper explains the approach with the help of Area and Water Allocation Model (AWAM) which uses the simulation-optimization technique for optimum allocation of land and water resources to different crops grown in different allocation units of the irrigation scheme.
\end{abstract}

\footnotetext{
${ }^{1}$ Associate Professor, Mahatma Phule Agricultural University, Rahuri, India-413722 and Academic Visitor, Loughborough University, UK (E-mail: S.D.Gorantiwar@lboro.ac.uk)

2 Director, (E-mail: I.K.Smout@lboro.ac.uk; Fax: +44 (0) 1509211079

${ }^{3}$ Senior Lecturer (E-mail: K.Vairavamoorthy@lboro.ac.uk)

Water Engineering and Development Centre (WEDC), Department of Civil and Building Engineering, Loughborough University, Loughborough, Leicestershire, LE11 3TU
} 


\section{INTRODUCTION}

The planning for irrigation water management in an irrigation scheme consists of the preparation of an allocation plan for distribution of land and water resources to different crops up to tertiary or farm level, and water delivery schedules in terms of timing and amount of water delivery for this allocation plan according to the set objectives/targets. One of the oldest problems in this planning has been how to divide the shared and limited water resources amongst the multiple users efficiently and equitably by addressing the social, economic and political issues, while considering the heterogeneity in soils, crops and climate and complexity of the water distribution system (Chambers 1988; Gorantiwar and Smout, 2003 and Unal et al 2004). In the past, several methodologies have been developed to prepare the allocation plans during the planning process. On the basis of dealing with the performance measures such as productivity and equity, these methodologies can be classified in three categories as i) methodologies aiming for only optimum productivity, ii) methodologies aiming for optimum productivity while addressing the issue of equity and iii) methodologies aiming for optimum productivity and/or maximum equity.

Much of the literature on allocation of land and water resources focused on the first category i.e. optimizing productivity (Matanga and Marino 1979; Yaron and Dinar 1982; Loftis and Houghtalen 1987; Bernardo et al. 1988; Abderrahman et al. 1989;

Hiessl and Plate 1990; Rao et al. 1990; Vedula and Mujumdar 1992; Mannocchi and Mecarelli 1994; Akhand et al. 1995; Mainuddin et al. 1996; Sunantara and Ramirez, 1997; Wardlaw and Barnes 1999; Paul et al. 2000 and Sahoo et al. 2001). The models used in these studies were of single field type. Therefore these models could not 
consider the distribution of resources (land to be irrigated, and water) by allocation units or fields and hence the water delivery schedules for the allocation plans were not discussed. Therefore the issue of equity was not addressed.

Previous studies that used the multi field type of model (Sritharan et al. 1988 and Shyam et al. 1994) produced the allocation plans and water delivery schedules for each allocation unit or field for optimum productivity. These studies discussed or estimated the performance measure of equity for the optimum allocation plan, as they obtained the distribution of the resources by allocation unit. Therefore the methodologies included in these models fall in the second category of methodologies, which optimize productivity while addressing the issue of equity. However these models did not aim for optimization or maximization of the equity. The models which are of simulation in nature such as reported by Keller (1987); Jian (1990) and Steiner and Walter (1992) estimated the equity for the given land and water resources allocation plan or for specified crop areas and water distribution rule. But these models did not attempt to optimize productivity or equity.

The consideration of equity in the process of area and water allocation itself (third category) is an important social aspect of irrigation water management (Abernethy 1986; Chambers 1988 and Samapth 1989) and hence needs to be included while developing the allocation plans. Burton (1994), Onta et al. (1995) and Small and Rimal (1996) maximized the area proportionate equity in water distribution while developing the allocation plans as discussed below.

Burton (1994) used the simulation model "Computer Aided Management and Simulation of Irrigation systems (CAMSIS)" to allocate water according to different 
policies including maximum benefits and maximum equity policies to previously determined or cultivated crop areas. He applied the model to a pumped irrigation scheme in East Africa. As the water was allocated to the previously determined area, the study did not consider optimization of productivity by varying the irrigated area.

Onta et al. (1995) considered full irrigation supply to crops (constrained by the local situation in Kankai Irrigation System in Nepal) for maximizing net benefits. However as they considered only one irrigation strategy i.e. full irrigation for each crop, they could optimize the use of land resources only, though optimization of both land and water resources would have achieved more productivity. They included the maximization of equity by estimating the proportionate available water supply to each allocation unit external to the model. Evans et al (2003) also adopted a similar approach for development of an optimization model for achieving efficiency and equity in irrigation management for El Angel watershed, Carchi, Ecuador. Small and Rimal (1996), while studying the effects of alternative water distribution rules on irrigation system performance of hypothetical rice based irrigation system in Asia, also estimated the area proportionate allocation of water to each block cultivated with the single crop of paddy external to the model and applied the model "Simulated Irrigated Rice System (SIRS)" to determine the yields of paddy. Estimating the area proportionate water allocation to different allocation units outside the allocation process can not represent the water losses associated with the process of conveyance and distribution properly and hence the maximum equity could not be achieved in the studies by Onta et al., Evans et al. and Small and Rimal.

Kalu et al. (1995) developed the allocation plans by varying the parameter which influenced equity (fraction of area of each field plot to be irrigated and level of water 
application), while minimizing water losses (or maximizing system efficiency) and in the process developed the allocation plans for maximum equity. Wardlaw and Barnes (1996) and Wardlaw and Barnes (1999) presented an approach which maximizes crop production (or minimizes crop losses) from previously allocated crop areas, while maintaining equity (in yield response or water allocation) between different irrigation schemes and allocation units within schemes during a particular irrigation period. They applied this approach to Lower Ayung River Basin in Indonesia. Kipkorir et al. (2001) extended this approach by developing an optimization model for allocation of water resources to specified crop areas in each allocation unit (area allocation plan) during a particular irrigation period or the series of consecutive irrigation periods when supply is less than demand, for maximization of net benefits, equitable yield, equitable benefits and equitable water supply during these periods. They assessed the potential of their model through application to Perkerra Irrigation Scheme in Kenya. The models developed by Wardlaw and Barnes and Kipkorir et al. allocate the water to previously assumed crop areas in different fields or allocation units, which themselves may not be equitable, and these models are applicable for run-of-river systems. Nevertheless, these studies are important for considering equity while developing the optimum allocation plans and distribution schedules.

Equity in general may be defined as the allocation and delivery of an equitable share of water to the users throughout the irrigation scheme based on certain criteria such as a fixed proportion according to the land holdings of different farmers. However equity has multidimensional aspects (Abernethy 1989) and often conflicts with the other important performance measures (Gorantiwar 1995; Kalu et al. 1995; Onta et al. 1995 and Small and Rimal 1996). Therefore inclusion and analysis of equity in the allocation process needs an emphasis on all dimensions of equity. With the fruits of irrigation 
known to everybody, farmers in the command area are more concerned about how they can get more water for their own fields, adequate water, reliable supply and increased productivity. Thus it is important that irrigation managers know the allocation plans which would optimize productivity and equity and then adopt an appropriate plan depending on the underlying objectives/goal and the local situation. Such plans will also help them to achieve the required balance between productivity and equity. This paper presents the procedure for including the optimization of performance measures such as productivity and equity in the allocation process.

\section{APPROACH}

Most of the studies cited earlier focused only on the optimization of the productivity while developing the allocation plans. Though some of the studies addressed the issue of equity as elaborated above, its consideration was limited to allocating water to previously cultivated area, or equitable water allocation was estimated outside the allocation process. However the local situations may need maximizing equity, while optimizing the productivity. Equitable water supply is the main feature of the Warabandi water distribution system practiced in Northern Indian and Pakistan (Malhotra, 1982) and Shejpali in central India (Mandavi, 1998). In all these systems optimization of total production or net benefits is the inherent objective, which is enveloped by the objective of maximizing equity. As these performance measures conflict with each other, optimizing one performance measure may weaken another performance measure. Thus it is also necessary to know the influence of optimizing one performance measure on the other. 
The flowchart in Fig. 1 explains the procedure to develop the allocation plans for optimum productivity and/or equity. The model 'Area and Water Allocation Model (AWAM)' (Gorantiwar, 1995 and Smout and Gorantiwar 2005) developed by the authors is used in this study for addressing the issue of optimum productivity. The AWAM model generates the irrigation strategies for different irrigation policies, and simulates the crop yield and total net benefits derived from irrigating different crops on different soils in different allocation units for these irrigation strategies. It then develops the allocation plan and the water delivery schedules for the operational objective of maximizing the output (total net benefits or crop yield) within different physical and

resources restrictions. The AWAM model and procedure developed to include maximization of equity while optimizing the productivity through total net benefits are described briefly below.

\section{MODEL DESCRIPTION}

The AWAM model has the following four phases and is executed for each set of irrigation intervals over the irrigation season (Fig. 2).
1. Generation of irrigation strategies
2. Preparation of irrigation programs
3. Selection of irrigation programs
4. Optimum allocation of resources

\section{Phase 1: Generation of irrigation strategies}

The four different irrigation policies based on applying the irrigation at each predecided irrigation interval are included in the model. The irrigation strategies for estimating the depth of irrigation to be applied at each irrigation for each irrigation policy is described below. The irrigation strategies need to be generated for each CSR 
unit (the unit with similar Crop, Soil and Climate or Region in an irrigation scheme but not a physical division of the irrigation scheme).

i) Optimized deficit irrigation: Whenever there is conflict between water supply and demand, deficit irrigation may be beneficial (Hargreaves and Samani, 1984; English, 1990; Keller et al., 1992 and Gorantiwar and Smout, 2003). There are several ways to provide deficit irrigation for a specified CSR unit in an irrigation scheme and therefore there is a need to select the optimal way by considering all CSR units, water availability and characteristics of the command area of the irrigation scheme together (the optimum selection is done at Phase-4). The several possible ways that are based on different combinations of deficit (percentage moisture stress in the soil root zone on the day of irrigation) over all the irrigation periods are generated for each CSR unit in this phase (Phase 1). Each of these ways is referred to as an 'irrigation strategy'. These irrigation strategies result in variable depths of irrigation for each irrigation. At this stage, several irrigation strategies are generated for a given set of irrigation intervals, for inclusion in the allocation process. The detailed procedure for generation of irrigation strategies for the irrigation policy of 'optimized deficit irrigation' is presented by Gorantiwar and Smout (2003).

ii) Fixed depth irrigation: The irrigation strategy is to apply the fixed depth of irrigation to all CSR units for all irrigations.

iii) Full irrigation: The irrigation strategy is to apply water to fill the crop root zone to field capacity considering the heterogeneity in the irrigation scheme (full irrigation depth). The full irrigation depth differs from irrigation to irrigation, crop to crop and soil to soil and the application, distribution and conveyance efficiencies influence the water required to be delivered from the headwork so that full irrigation is applied at the farm. 
iv) Prescribed: The irrigation strategy is to prescribe a deficit or an irrigation depth for each CSR unit for each irrigation.

\section{Phase 2: Preparation of irrigation program}

The irrigation program which consists of information on irrigation requirement (depth) per irrigation and yield/benefits is prepared for irrigation strategy(ies) generated in Phase-1 for the specified irrigation policy (note that for 'optimized deficit irrigation' policy, there is more than one irrigation strategy for each CSR unit), with the following two submodels.

- SWAB: This submodel simulates soil moisture in the soil root zone and estimates the actual crop evapotranspiration and the other related parameters and the irrigation requirement (depth) per irrigation.

- CRYB: This submodel estimates crop yield and net benefits.

The details of these two sub models can be found in Gorantiwar (1995) and Gorantiwar and Smout (2003).

\section{Phase 3: Selection of irrigation programs}

Phase-1 generates several irrigation strategies and hence Phase-2 produces several irrigation programs for the irrigation policy of optimized deficit irrigation. Not all of them are important and not all can be used in the fourth phase due to computational limitations. Therefore this phase selects a specified number of irrigation programs, which are both optimal and efficient according to certain criteria for each CSR unit. Smout and Gorantiwar (2005) have elaborated the procedure for selection of irrigation programs. 


\section{Phase 4: Optimum allocation of resources}

In this phase the model allocates land and water resources optimally to different crops cultivated on different soils in different allocation units. It utilizes the irrigation programs produced/selected in Phase-2/Phase-3. For this purpose, the entire irrigation scheme is physically divided into a number of smaller units called "Allocation Units" (AU) over which land and water resources are allocated. The climate is assumed to be uniform over the AU, but the AU may include different soils and crops. The climatic conditions may be different for different AUs. The need to divide the irrigation scheme into several allocation units arises due to the heterogeneous nature and large extent of the irrigation scheme and in order to make allocation of resources, water delivery schedules and management of the irrigation scheme efficient. The largest possible size of the AU is equivalent to the size of the irrigation scheme itself. The smallest size of the AU is the individual farm. The intermediate sizes are the command area of the secondary, tertiary and quaternary canals or their groups. This phase allocates land and water resources optimally to different crops grown on different soils in different allocation units for different objectives through following three stages.

- Stage 1: Preparation of irrigation programs for each Crop-Soil (a unit with similar crop and soil) (CS) unit of AU by modifying the irrigation programs of the corresponding CSR unit considering the distribution and conveyance efficiencies.

- Stage 2: Allocation of the resources to each CS unit of AU with chosen objective(s) and constraints with the Resource Allocation (RA) submodel. The operational objective is the optimization of productivity (maximization of total net benefits). The maximization of equity is included through the constraints. The other constraints included are: total water use, physical constraints, resource 
availability constraints and output requirement constraints. This model is solved by linear programming.

- Stage 3: The preparation of a water release schedule for the canal system for the selected allocation plan.

The objective function (optimization of productivity) and constraints developed for maximization of equity are described below. The readers are advised to refer to Gorantiwar (1995) and Smout and Gorantiwar (2005) for other details.

\section{Objective function}

The decision variable is the area to be allocated for irrigation to a particular crop cultivated on a particular soil (CS) of a particular AU and following a particular irrigation program prepared for the corresponding $\mathrm{CS}$ of $\mathrm{AU}$ ('A' in equation 1).

$\operatorname{Max} \quad \mathrm{OBJ}=\sum_{\mathrm{a}=1}^{\mathrm{na}} \sum_{\mathrm{s}=1}^{\mathrm{ns}_{\mathrm{a}}} \sum_{\mathrm{c}=1}^{\mathrm{nc}_{\mathrm{sa}}} \sum_{\mathrm{p}=1}^{\mathrm{np}_{\mathrm{csa}}} \mathrm{NB}_{\mathrm{pcsa}} \mathrm{A}_{\mathrm{pcsa}}$

where $\mathrm{a}=$ index for $\mathrm{AU}, \mathrm{s}=$ index for soil group in allocation unit, $\mathrm{c}=$ index for crop in soil group ( $\mathrm{s}^{\text {th }}$ soil group of $\mathrm{a}^{\text {th }}$ allocation unit), $\mathrm{p}=$ index for irrigation program for crop ( $\mathrm{c}^{\text {th }}$ crop in $\mathrm{s}^{\text {th }}$ soil group of $\mathrm{a}^{\text {th }}$ allocation unit), na $=$ total number of allocation units, $\mathrm{ns}_{\mathrm{a}}$ $=$ total number of soil groups in $\mathrm{a}^{\text {th }}$ allocation unit., $\mathrm{nc}_{\mathrm{sa}}=$ total number of crops in $\mathrm{s}^{\text {th }}$ soil group of $\mathrm{a}^{\text {th }}$ allocation unit, $\mathrm{nsp}_{\mathrm{csa}}=$ total number of irrigation programs of $\mathrm{c}^{\text {th }}$ crop in $\mathrm{s}^{\text {th }}$ soil group of $\mathrm{a}^{\text {th }}$ allocation unit, $\mathrm{OBJ}=$ the value of objective function (currency unit), NB $=$ net benefits obtained from $c^{\text {th }}$ crop irrigated with $\mathrm{p}^{\text {th }}$ irrigation program on 
$\mathrm{s}^{\text {th }}$ soil of $\mathrm{a}^{\text {th }}$ allocation unit (currency unit/ha), $\mathrm{A}=$ Area to be allocated to $\mathrm{c}^{\text {th }}$ crop irrigated with $\mathrm{p}^{\text {th }}$ irrigation program on $\mathrm{s}^{\text {th }}$ soil of $\mathrm{a}^{\text {th }}$ allocation unit (ha).

\section{Equity constraints}

Previous studies attempt to maximize the equity in area allocation (Malhotra et al. 1984 and Sampath 1988) or water allocation (Burton 1994; Onta et al. 1995; Kalu et al. 1995 and Small and Rimal 1996). The final objective of the allocation may be to achieve equity in distribution of output from the irrigation scheme. In these models, which consider only land allocation and assume the soil in the scheme is homogenous, climate is uniform and various losses are not location specific, the particular depth of water diverted from the headworks for irrigating a certain crop results in the same output everywhere. In this case equity in area allocation and water distribution are the same and result in fair distribution of output. But when the heterogeneity in soil, climate and losses is also considered, the equity in area allocation and water distribution produce differing results and the output distribution among various users may not be fair. Therefore the consideration of equity in distribution of output (crop production and net benefits) is also important. Wardlaw and Barnes (1999) and Kipkorir et al. (2001) considered the equity in yield response, but these studies are limited to the allocation to previously specified crop areas and run-of-river irrigation systems. Thus the following four means of achieving equity are incorporated in the model through the equity related constraints, and these are considered in turn below.
1) Crop Area
2) Water
3) Crop production and
4) Net benefits

It is also important to include in the allocation process the base on which equity should be achieved along with the means of achieving equity. All the previously 
described models tried to achieve equity in distribution of crop area or water or output produced proportional to the land holding. However there are several arguments over the base of equity. It may be possible that in a scheme with inequitable distribution of water, land towards the head of the system will have a high land price and as a result farmers are likely to have lower land holdings at the head end than the tail end farmers who may be able to buy more land with the same funds (Abernethy, 1986). In this case allocating water according to the land holding may not be fair. According to Levine and Coward (1989), for water allocation, the equity may be based on seniority of water rights of the irrigator, severity of water needed by crops, time or resource sharing on a canal, allocation based on land holdings and water allocation based on family size. According to Molden and Gates (1990), the fair sharing of water may be based on a legal right for water or it may be set as a fixed proportion of the water supply. The base for equity together with the means for achieving equity are presented in Fig.3.

In this model, the base for equity in the allocation process is included through 'desired allocation proportion' $(\lambda d)$ which indicates the proportion of resources to be allocated to or the outputs to be ensured for a specified allocation unit out of the total resources available or total estimated outputs. Thus the desired allocation proportion for the specified allocation unit is the ratio of the value of the base for the specified allocation unit, to which equity should be proportional, and the total value of the base (equation 2).

$$
\lambda \mathrm{d}_{\mathrm{a}}=\frac{\Delta \mathrm{d}_{\mathrm{a}}}{\sum_{\mathrm{a}=1}^{\mathrm{na}} \Delta \mathrm{d}_{\mathrm{a}}}
$$


Where, $\lambda d_{a}=$ desired allocation proportion for equity and $\Delta d_{a}=$ the value of the base to which equity should be proportional, assigned to $\mathrm{a}^{\text {th }}$ allocation unit.

If the culturable command area or land holding of the allocation unit is considered as the base of equity, the desired allocation proportion $\left(\lambda \mathrm{d}_{\mathrm{a}}\right)$ for different allocation units is computed by equation (3). However as stated above, the desired allocation proportion may be based on some other considerations.

$$
\lambda d_{a}=\frac{T A_{a}}{\sum_{a=1}^{n a} T A_{a}}
$$

where, $\mathrm{TA}_{\mathrm{a}}$ is the total culturable area or land holding of $\mathrm{a}^{\text {th }}$ allocation unit (ha)

1) Equity in Crop Area: By this means, the crop area is allocated for irrigation to the different allocation units as per given value of desired allocation proportion for equity $\left(\lambda d_{a}\right)$ for different allocation units

$$
\sum_{\mathrm{s}=1}^{\mathrm{ns}_{\mathrm{a}}} \sum_{\mathrm{c}=1}^{\mathrm{nc}_{\mathrm{sa}}} \sum_{\mathrm{p}=1}^{\mathrm{np}_{\mathrm{csa}}} \mathrm{A}_{\mathrm{pcsa}}=\lambda \mathrm{d}_{\mathrm{a}} \sum_{\mathrm{a}=1}^{\mathrm{na}} \sum_{\mathrm{s}=1}^{\mathrm{ns}_{\mathrm{a}}} \sum_{\mathrm{c}=1}^{\mathrm{nc}_{\mathrm{sa}}} \sum_{\mathrm{p}=1}^{\mathrm{np}_{\mathrm{csa}}} \mathrm{A}_{\mathrm{pcsa}} \quad \text { for } \quad \mathrm{a}=1, \mathrm{na}
$$

This aspect may not result in proportionate distribution of output as the soil, climate and water losses influence the output. However in case of fixed depth irrigation policy, the equity in crop area and water distribution should be same.

2) Equity in Water: By this means the water is distributed to different allocation units as per the value of desired allocation proportion for equity. Malhotra (1982), Latif and 
Sarwar (1994) and Khepar et al. (2000) raised the concern over equitable water allocation aspect of 'Warabandi', which does not consider the seepage or conveyance losses in the distribution system while deciding the area proportionate water allocation. Therefore, the farmers situated at tail end receive proportionally less water than the farmers at head of the water distribution system. If the conveyance losses are considered, the allocation units at far ends or towards tail of the system will be compensated for the losses and will receive the comparable share of water to those received by the allocation units at the head of the system. However by giving equal importance to the allocation units at the tail of the system (by compensating for the conveyance losses), the productivity of the irrigation scheme may be hampered because of excessive loss of water in the conveyance process. Similarly if distribution losses are considered, the allocation units with poor distribution networks will be compensated for the losses in distribution of water within the allocation unit. But again by giving the equal importance to the allocation units with poor and efficient distribution networks, the productivity of the irrigation scheme may be reduced because of excessive loss of water in the distribution network in the allocation unit. Thus the consideration of the losses at different levels in the water distribution system is a complex issue, influencing both productivity and equity. An irrigation manager may choose, therefore, to distribute water by considering conveyance and distribution losses, or by considering conveyance losses only, or without considering any of these losses.

The allocation of water is not only a spatial issue but also temporal. Therefore the developed model considers both seasonal/annual and intraseasonal/irrigation-wise equity in water allocation.

A) Seasonal/Annual Equity 
The seasonal or annual equity in water allocation is required when the irrigation scheme derives water from the storage reservoir.

i) Without considering losses (conveyance and distribution) in allocation

$$
\sum_{\mathrm{s}=1}^{\mathrm{ns}_{\mathrm{a}}} \sum_{\mathrm{c}=1}^{\mathrm{nc}_{\mathrm{csa}}} \sum_{\mathrm{p}=1}^{\mathrm{np}_{\text {csa }}} \mathrm{SWD}_{\mathrm{pcsa}} \mathrm{A}_{\mathrm{pcsa}}=\lambda \mathrm{d}_{\mathrm{a}} \sum_{\mathrm{a}=1}^{\mathrm{na}} \sum_{\mathrm{s}=1}^{\mathrm{ns}_{\mathrm{a}}} \sum_{\mathrm{c}=1}^{\mathrm{nc}_{\mathrm{sag}}} \sum_{\mathrm{p}=1}^{\mathrm{np}_{\text {csa }}} \mathrm{SWD}_{\mathrm{pcsa}} \mathrm{A}_{\mathrm{pcsa}} \quad \text { for } \quad \mathrm{a}=1, \mathrm{na}
$$

ii) Considering conveyance losses only in allocation

$$
\begin{aligned}
& \sum_{\mathrm{s}=1}^{\mathrm{ns}_{\mathrm{a}}} \sum_{\mathrm{c}=1}^{\mathrm{nc}_{\mathrm{sa}}} \sum_{\mathrm{p}=1}^{\mathrm{np}_{\mathrm{csa}}} \sum_{\mathrm{i}=1}^{\mathrm{I}} \mathrm{WD}_{\mathrm{ipcsa}} \eta \mathrm{na}_{\mathrm{ia}} \mathrm{A}_{\mathrm{pcsa}}=\lambda \mathrm{d}_{\mathrm{a}} \sum_{\mathrm{a}=1}^{\mathrm{na}} \sum_{\mathrm{s}=1}^{\mathrm{ns}_{\mathrm{a}}} \sum_{\mathrm{c}=1}^{\mathrm{nc}_{\mathrm{sa}}} \sum_{\mathrm{p}=1}^{\mathrm{np}_{\mathrm{csa}}} \sum_{\mathrm{i}=1}^{\mathrm{I}} \mathrm{WD}_{\mathrm{ipcsa}} \eta \mathrm{ca}_{\mathrm{ia}} \mathrm{A}_{\mathrm{pcsa}} \\
& \text { for } \quad a=1, n a
\end{aligned}
$$

iii) Considering losses (conveyance and distribution) in allocation

$$
\begin{gathered}
\sum_{\mathrm{s}=1}^{\mathrm{ns}_{\mathrm{a}}} \sum_{\mathrm{c}=1}^{\mathrm{nc}_{\mathrm{sa}}} \sum_{\mathrm{p}=1}^{\mathrm{np}_{\mathrm{csa}}} \sum_{\mathrm{i}=1}^{\mathrm{I}} \mathrm{WD}_{\mathrm{ipcsa}}\left(\eta c \mathrm{a}_{\mathrm{ia}} \eta \mathrm{da} \mathrm{ia}_{\mathrm{ia}}\right) \mathrm{A}_{\mathrm{pcsa}}=\lambda \mathrm{d}_{\mathrm{a}} \sum_{\mathrm{a}=1}^{\mathrm{na}} \sum_{\mathrm{s}=1}^{\mathrm{ns}_{\mathrm{s}}} \sum_{\mathrm{c}=1}^{\mathrm{nc}_{\mathrm{sa}}} \sum_{\mathrm{p}=1}^{\mathrm{np}_{\mathrm{csa}}} \sum_{\mathrm{i}=1}^{\mathrm{I}} \mathrm{WD}_{\mathrm{ipcsa}}\left(\eta c \mathrm{a}_{\mathrm{ia}} \eta \mathrm{da} \mathrm{i}_{\mathrm{ia}}\right) \mathrm{A}_{\mathrm{pcsa}} \\
\text { for } \quad \mathrm{a}=1 \text {, na }
\end{gathered}
$$

where,

$$
\mathrm{WD}_{\mathrm{ipcsa}}=\frac{\mathrm{ID}_{\mathrm{ipcsa}}}{\eta \mathrm{ca}_{\mathrm{ia}} \eta \mathrm{da} \mathrm{ia}_{\mathrm{ia}}}
$$

$\mathrm{i}=$ index for irrigation, $\mathrm{I}=$ total number of irrigations, $\mathrm{WD}_{\mathrm{ipcsa}}=$ the depth of water to be delivered from the headworks to $c^{\text {th }}$ crop irrigated with $\mathrm{p}^{\text {th }}$ irrigation program on $\mathrm{s}^{\text {th }}$ 
soil of $\mathrm{a}^{\text {th }}$ allocation unit for $\mathrm{i}^{\text {th }}$ irrigation $(\mathrm{m}), \mathrm{ID}=$ depth of water to be applied to $\mathrm{c}^{\text {th }}$ crop irrigated with $\mathrm{p}^{\text {th }}$ irrigation program on $\mathrm{s}^{\text {th }}$ soil of $\mathrm{a}^{\text {th }}$ allocation unit for $\mathrm{i}^{\text {th }}$ irrigation (m), $\eta \mathrm{ca}_{\mathrm{ia}}=$ conveyance efficiency of canal network for $\mathrm{i}^{\text {th }}$ irrigation for $\mathrm{a}^{\text {th }}$ allocation unit (fraction), $\eta \mathrm{da}_{\mathrm{ia}}=$ distribution efficiency for $\mathrm{i}^{\text {th }}$ irrigation of $\mathrm{a}^{\text {th }}$ allocation unit (fraction), $\mathrm{SWD}_{\mathrm{pcsa}}=$ the seasonal depth of water to be delivered from the headworks to $c^{\text {th }}$ crop irrigated with $\mathrm{p}^{\text {th }}$ irrigation program on $\mathrm{s}^{\text {th }}$ soil of $\mathrm{a}^{\text {th }}$ allocation unit $(\mathrm{m})$.

B) Intraseasonal/ irrigation-wise Equity

When the allocation of water during individual irrigation period is necessary based on equity for example for the irrigation schemes which derive water from the direct river runoff, the constraints represented by equations (5) to (7) are modified to the constraints represented by equations (9) to (11).

i) Without considering losses (conveyance and distribution) in allocation

$$
\begin{aligned}
& \sum_{\mathrm{s}=1}^{\mathrm{ns}_{\mathrm{a}}} \sum_{\mathrm{c}=1}^{\mathrm{nc}_{\mathrm{sa}}} \sum_{\mathrm{p}=1}^{\mathrm{np}_{\mathrm{csa}}} \mathrm{WD}_{\mathrm{ipcsa}} \mathrm{A}_{\mathrm{pcsa}}=\lambda \mathrm{d}_{\mathrm{a}} \sum_{\mathrm{a}=1}^{\mathrm{na}} \sum_{\mathrm{s}=1}^{\mathrm{ns}_{\mathrm{a}}} \sum_{\mathrm{c}=1}^{\mathrm{nc}_{\mathrm{sa}}} \sum_{\mathrm{p}=1}^{\mathrm{np}_{\mathrm{csa}}} \mathrm{WD}_{\mathrm{ipcsa}} \mathrm{A}_{\mathrm{pcsa}} \quad \text { for } \quad \mathrm{i}=1, \mathrm{I} \quad \text { and } \\
& a=1 \text {,na }
\end{aligned}
$$

ii) Considering conveyance losses only in allocation

$$
\begin{aligned}
& \sum_{\mathrm{s}=1}^{\mathrm{ns}_{\mathrm{a}}} \sum_{\mathrm{c}=1}^{\mathrm{nc}_{\mathrm{sa}}} \sum_{\mathrm{p}=1}^{\mathrm{np}_{\mathrm{csa}}} \mathrm{WD}_{\mathrm{ipcsa}} \eta \mathrm{ca}_{\mathrm{ia}} \mathrm{A}_{\mathrm{pcsa}}=\lambda \mathrm{d}_{\mathrm{a}} \sum_{\mathrm{a}=1}^{\mathrm{na}} \sum_{\mathrm{s}=1}^{\mathrm{ns}_{\mathrm{s}}} \sum_{\mathrm{c}=1}^{\mathrm{nc}_{\mathrm{sa}}} \sum_{\mathrm{p}=1}^{\mathrm{np}_{\mathrm{csa}}} \mathrm{WD}_{\mathrm{ipcsa}} \eta \mathrm{ca}_{\mathrm{ia}} \mathrm{A}_{\mathrm{pcsa}} \quad \text { for } \quad \mathrm{i}=1, \mathrm{I} \quad \text { and } \\
& a=1 \text {,na (10) }
\end{aligned}
$$

iii) Considering losses (conveyance and distribution) in allocation 


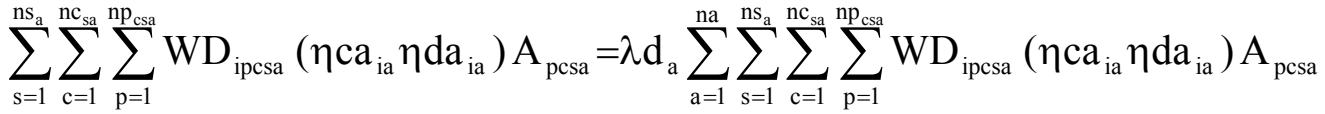

$$
\begin{aligned}
& \text { for } i=1, I \text { and } \\
& \mathrm{a}=1, \mathrm{na}
\end{aligned}
$$

Equitable distribution of input (area or water allocation) is different than the equitable distribution of output (crop production or net benefits). The equity in input does not consider the effect of varying soil and climate in the scheme that produce varying output while distributing the resources. Varying soils and climate in the scheme can be considered by proportional distribution of output (crop production and net benefits) in the allocation process. This is described below.

3) Equity in Crop production: By this means the resources are allocated in a way to obtain the crop production to different users as per the proportion.

$$
\begin{aligned}
\sum_{\mathrm{s}=1}^{n \mathrm{~s}_{\mathrm{a}}} \sum_{\mathrm{c}=1}^{\mathrm{nc}_{\mathrm{sa}}} \sum_{\mathrm{p}=1}^{\mathrm{np}_{\mathrm{csa}}} \mathrm{Ya}_{\mathrm{pcsa}} \mathrm{A}_{\mathrm{pcsa}}=\lambda \mathrm{d}_{\mathrm{a}} \sum_{\mathrm{a}=1}^{\mathrm{na}} \sum_{\mathrm{s}=1}^{\mathrm{ns}_{\mathrm{a}}} \sum_{\mathrm{c}=1}^{\mathrm{nn}_{\mathrm{sa}}} \sum_{\mathrm{p}=1}^{\mathrm{np}_{\mathrm{csa}}} \mathrm{Ya}_{\mathrm{pcsa}} \mathrm{A}_{\mathrm{pcsa}} & \text { for } \quad \mathrm{a}=1, \text { na } \\
& \text { when } \mathrm{nc}_{\mathrm{sa}}=1 \text { for all na }
\end{aligned}
$$

where $Y a_{\text {pcsa }}=$ yield estimated from $c^{\text {th }}$ crop irrigated with $\mathrm{p}^{\text {th }}$ irrigation program on $\mathrm{s}^{\text {th }}$ soil of $\mathrm{a}^{\text {th }}$ allocation unit $(\mathrm{Kg} / \mathrm{ha})$.

4) Equity in Net benefits: In multicrop situation crop production can not be used as output, as yields obtained from different crops are not comparable. Therefore equity in 
net benefits need to be considered. Thus in this case the expected net benefits obtained from irrigating the land should be distributed as per the proportion for equity

$\sum_{\mathrm{s}=1}^{\mathrm{ns}_{\mathrm{a}}} \sum_{\mathrm{c}=1}^{\mathrm{nc}_{\mathrm{sa}}} \sum_{\mathrm{p}=1}^{\mathrm{np}_{\mathrm{csa}}} \mathrm{NB}_{\mathrm{pcsa}} \mathrm{A}_{\mathrm{pcsa}}=\lambda \mathrm{d}_{\mathrm{a}} \sum_{\mathrm{a}=1}^{\mathrm{na}} \sum_{\mathrm{s}=1}^{\mathrm{ns}_{\mathrm{a}}} \sum_{\mathrm{c}=1}^{\mathrm{nc}_{\mathrm{sa}}} \sum_{\mathrm{p}=1}^{\mathrm{np}_{\mathrm{css}}} \mathrm{NB}_{\mathrm{pcsa}} \mathrm{A}_{\mathrm{pcsa}} \quad$ for $\quad \mathrm{a}=1, \mathrm{na}$

where $\mathrm{NB}_{\mathrm{pcsa}}=$ net benefits estimated from $\mathrm{c}^{\text {th }}$ crop irrigated with $\mathrm{p}^{\text {th }}$ irrigation program on $\mathrm{s}^{\text {th }}$ soil of $\mathrm{a}^{\text {th }}$ allocation unit (currency unit/ha).

\section{Inequity Constraints}

As stated earlier equity is an equitable distribution of input (land area allocated for irrigation or water) or output (crop production or net benefits) to the users throughout an irrigation scheme according to certain criteria. The constraints presented by equations (4) to (13) produce the perfect equity (equity of one) in terms of different means (for example, area, water, net benefits and crop production) amongst all the allocation units or users. However in many situations equity less than one or inequity is needed for fulfilling certain legal rights or for social reasons. For example in cases where the allocation units at the head of system need to be allocated more water because of their 'right to use water first'. Similarly some inequity may be needed to guarantee social sustainability by improving the quality of life of poor and marginal farmers (Levite and Sally, 2002). In this case, the farmers with marginal or less holdings need to be given a higher proportion of water than their equitable share over the farmers with large land holdings so as to achieve 'social equity'. 
The consideration of inequity in the allocation process requires some modifications to equity constraints (equations 4 to 13). For inequity, the expected output (right hand side of equations 4 to 13) should be more or less than the desired output (left hand side of equations 4 to 13) depending on whether the specified allocation units need more or less proportion of water over the fixed proportion (an equitable share) based on certain consideration. In this case the desired output should be estimated based on the value of desired allocation proportion for inequity, $\gamma \mathrm{d}_{\mathrm{a}}$. This is not the desired allocation proportion of equity, $\lambda d_{a}$, based on certain parameter (for example area in equation 3 ), but some value based on desired weighting to $\lambda d_{a}$ (for example the allocation units at the head of system having more weightage to $\lambda d_{a}$ than the allocation units at the tail of system for the 'right to use water first' situation or the small or marginal farmer's allocation units having more weightage to $\lambda \mathrm{d}_{\mathrm{a}}$ than the larger farmer's allocation units). The desired allocation proportion for inequity, $\gamma \mathrm{d}_{\mathrm{a}}$, is estimated with the help of equation (14). $\lambda d_{a}$ in equations (4) to (13) should be replaced by $\gamma d_{a}$ for inequity.

$$
\gamma \mathrm{d}_{\mathrm{a}}=\lambda \mathrm{d}_{\mathrm{a}}+\omega_{\mathrm{a}}
$$

$$
\sum_{\mathrm{a}=1}^{\mathrm{na}} \omega_{\mathrm{a}}=0
$$

where $\gamma \mathrm{d}_{\mathrm{a}}=$ desired allocation proportion for inequity for $\mathrm{a}^{\text {th }}$ allocation unit and $\omega_{\mathrm{a}}=$ weighting for $\mathrm{a}^{\text {th }}$ allocation unit required for inequity in allocation of water to different allocation units.

\section{Consideration of return flows}


As stated earlier when optimizing productivity and maximizing equity while allocating the resources to different allocation units, the consideration of the losses at different levels in the water distribution system influences both productivity and equity. The issue becomes more complex when these losses add to the groundwater or subsurface water system as return flows. For example while maximizing the equity, as the water is allocated to all allocation units including those at far end of the system, the conveyance losses will increase and hence productivity will reduce. Similarly when the conveyance losses are considered while maximizing the equity in the allocation process, the equity is increased by comparing the allocation units at far ends or towards tail of the system for the losses so that they receive the comparable share of water to those received by the allocation units at the head of the system. However in this process also, total conveyance losses will be increased and the productivity will be reduced. In both the cases when these losses add to the groundwater as the return flow which is then utilized by allocation units for irrigation of the additional land area, the productivity will be increased. This paper does not consider this contribution of losses to return flows that can be utilized for further irrigation, as the study is primarily concerned with the surface water irrigation schemes.

\section{CONCLUSIONS}

The irrigation schemes in the semi arid and arid regions in developing countries are characterized by water scarcity, the heterogeneity in soils, crops and climate, a complex water distribution network and the large number of users. Therefore the development of optimum land and water allocation plans and operable water delivery schedules are valuable for these irrigation schemes. According to the local situation, the

performance objectives of productivity and equity may be appropriate and it is 
important that irrigation managers have access to allocation plans and schedules which optimize productivity and equity. Earlier studies which aimed at producing the optimum allocation plans did not consider all these complexities and optimization of the performance measures together. This study presented the approach to develop the allocation plans and the water delivery schedules for optimization of different performance parameters such as productivity and equity. This approach considers the different dimensions of equity such as seasonal water distribution, water distribution per irrigation, benefits generated. It also includes distribution and conveyance losses while allocating water equitably to different allocation units. The inclusion of these performance parameters while developing the optimum allocation plans enables the irrigation authorities to select the appropriate allocation plans depending on the local situation and to match the performance of the irrigation scheme to the objectives/goals of the irrigation scheme. This paper has thus presented an investigation of different issues of allocating resources for agriculture amongst the multiple users. The application of this approach is considered in the companion paper (Smout et al. 2005). 


\section{APPENDIX I. NOTATIONS}

$\eta \mathrm{ca}_{\mathrm{ia}}=$ conveyance efficiency of canal network for $\mathrm{i}^{\text {th }}$ irrigation for $\mathrm{a}^{\text {th }}$ allocation unit (fraction)

$\eta \mathrm{da}_{\mathrm{ia}}=$ distribution efficiency for $\mathrm{i}^{\text {th }}$ irrigation of $\mathrm{a}^{\text {th }}$ allocation unit (fraction)

$A=$ Area to be allocated to $c^{\text {th }}$ crop irrigated with $\mathrm{p}^{\text {th }}$ irrigation program on $\mathrm{s}^{\text {th }}$ soil of $\mathrm{a}^{\text {th }}$ allocation unit (ha).

$\mathrm{a}=$ index for $\mathrm{AU}$

$\mathrm{AU}=$ Allocation Unit

$\mathrm{c}=$ index for crop in soil group $\left(\mathrm{s}^{\text {th }}\right.$ soil group of $\mathrm{a}^{\text {th }}$ allocation unit)

$\mathrm{CS}=$ Crop-Soil

CSR $=$ Crop-Soil-Region

$\mathrm{I}=$ total number of irrigations

$\mathrm{i}=$ index for irrigation

ID $=$ depth of water to be applied to $c^{\text {th }}$ crop irrigated with $p^{\text {th }}$ irrigation program on $s^{\text {th }}$ soil of $\mathrm{a}^{\text {th }}$ allocation unit for $\mathrm{i}^{\text {th }}$ irrigation $(\mathrm{m})$

na $=$ total number of allocation units

$\mathrm{NB}=$ net benefits obtained from $\mathrm{c}^{\text {th }}$ crop irrigated with $\mathrm{p}^{\text {th }}$ irrigation program on $\mathrm{s}^{\text {th }}$ soil of $\mathrm{a}^{\text {th }}$ allocation unit (currency unit/ha)

$\mathrm{NB}_{\mathrm{pcsa}}=$ net benefits estimated from $\mathrm{c}^{\text {th }}$ crop irrigated with $\mathrm{p}^{\text {th }}$ irrigation program on $\mathrm{s}^{\text {th }}$ soil of $a^{\text {th }}$ allocation unit (currency unit/ha)

$\mathrm{nc}_{\mathrm{sa}}=$ total number of crops in $\mathrm{s}^{\text {th }}$ soil group of $\mathrm{a}^{\text {th }}$ allocation unit

$\mathrm{ns}_{\mathrm{a}}=$ total number of soil groups in $\mathrm{a}^{\text {th }}$ allocation unit

$\mathrm{nsp}_{\mathrm{csa}}=$ total number of irrigation programs of $\mathrm{c}^{\text {th }}$ crop in $\mathrm{s}^{\text {th }}$ soil group of $\mathrm{a}^{\text {th }}$ allocation unit 
$\mathrm{OBJ}=$ the value of objective function (currency unit)

$\mathrm{p}=$ index for irrigation program for crop ( $\mathrm{c}^{\text {th }}$ crop in $\mathrm{s}^{\text {th }}$ soil group of $\mathrm{a}^{\text {th }}$ allocation unit)

$\mathrm{s}=$ index for soil group in allocation unit

$\mathrm{SWD}_{\mathrm{pcsa}}=$ the seasonal depth of water to be delivered from the headworks to $\mathrm{c}^{\text {th }}$ crop irrigated with $\mathrm{p}^{\text {th }}$ irrigation program on $\mathrm{s}^{\text {th }}$ soil of $\mathrm{a}^{\text {th }}$ allocation unit (m)

$\mathrm{TA}_{\mathrm{a}}=$ the total culturable area of $\mathrm{a}^{\text {th }}$ allocation unit (ha)

$\mathrm{WD}_{\text {ipcsa }}=$ the depth of water to be delivered from the headworks to $\mathrm{c}^{\text {th }}$ crop irrigated with $\mathrm{p}^{\text {th }}$ irrigation program on $\mathrm{s}^{\text {th }}$ soil of $\mathrm{a}^{\text {th }}$ allocation unit for $\mathrm{i}^{\text {th }}$ irrigation $(\mathrm{m})$

$\mathrm{Ya}_{\text {pcsa }}=$ yield estimated from $\mathrm{c}^{\text {th }}$ crop irrigated with $\mathrm{p}^{\text {th }}$ irrigation program on $\mathrm{s}^{\text {th }}$ soil of $\mathrm{a}^{\text {th }}$ allocation unit $(\mathrm{Kg} / \mathrm{ha})$

$\gamma \mathrm{d}_{\mathrm{a}}=$ desired allocation proportion for inequity

$\lambda \mathrm{d}_{\mathrm{a}}=$ the desired allocation proportion of inequity

$\omega_{\mathrm{a}}=$ weighting for $\mathrm{a}^{\text {th }}$ allocation unit required for inequity in allocation of water to different allocation units 


\section{APPENDIX II REFERENCES}

Abderrahman, W.A., Khan, A.U. and Eqnaibi, B.S. (1989) "Systems approach for irrigation management of complex projects involving a large number of farmers under severely arid regions." National Water Conference. Proceedings of the Speciality Conference, held at Newark, DE, USA:398-405.

Abernethy, C.L. (1986). Performance measurement in canal water management: A discussion. ODI-IIMI Irrigation Management Network Paper 86/2d, 25 pp.

Abernethy, C.L. (1989). Performance criteria for irrigation systems. In: J.R.Rydzewski and K.Ward (Eds) Proceedings on International Conference on Irrigation Theory and Practice, University of Southampton, U.K., 12-15 Sept, 1989.

Akhand, N. A., Larson, D. L. and Slack, D. C. (1995). "Canal irrigation allocation planning model.” Trans. ASAE, 38(2), 545-550.

Bernardo, D. J., Whittlesey, N. K., Saxton, K. E. and Bassett, D. L. (1988). “Irrigation optimization under limited water supply.” Trans. ASAE 31, (3), 712-719.

Burton, M.A. (1994). "A simulation of water allocation policies in times of water shortage.” Irrig. and Drain. Systems, 8, 61-81.

Chambers, R. (1988). Managing canal irrigation: Practical analysis from South Asia. Cambridge University Press, Cambridge, UK.

English, M. (1990). "Deficit irrigation I: Analytical framework.” J. Irrig. and Drain. Engrg., ASCE, 116(3), 399-412.

Evans, E.M., Lee, D.R., Boisvert, R.N., Arce, B., Steenhuis, T.S., Prano, M. and Poats, S.V. (2003). "Achieving efficiency and equity in irrigation management: an optimization model of the El Angel watershed, Carchi, Ecuador.” Agricultural Systems, 77:1-22. 
Gorantiwar, S. D. (1995). “A model for planning and operation of heterogeneous irrigation schemes in semi-arid regions under rotational water supply" $A P h . D$. Thesis, Loughborough University of Technology, Loughborough, Leicestershire, UK.

Gorantiwar, S.D. and Smout, I.K. (2003). "Allocation of scarce water resources using deficit irrigation in rotational systems. J. Irrig. and Drain. Engrg., ASCE, 129(3):155163.

Hargreaves, G. H. and Samani, Z. A. (1984). "Economic considerations of deficit irrigation.” J. Irrig. and Drain. Engrg., ASCE, 110(4), 343-358.

Hiess1, H. and Plate, E.J. (1990) “A heuristic closed-loop controller for water distribution in complex irrigation systems.” Water Resour. Res., 26(7), 1323-1333.

Jian, M. (1990). "Irrigation scheduling program for farm water delivery." Hydrosoft, $3(1), 19-23$

Kalu, I.L., Paudyal, G.N. and Gupta, A.D. (1995). "Equity and efficiency issues in irrigation water distribution.” Agricultural Water Management, 28, 335-348.

Keller, A.A. (1987). "Modeling Command Area Demand and Response to Water Delivered by the Main System." Ph.D. Thesis, Utah State University, Logan, Utah, USA.

Keller, J., Sivanappan, R. K. and Varadan, K. M. (1992). "Design logic for deficit drip irrigation of coconut trees." Irrig. and Drain. Systems, 6, 1-7.

Khepar, S.D., Gulati, H.S., Yadav, A.K. and Brar, T.P.S. (2000). “A model for equitable distribution for canal water.” Irrig. Sci., 19, 191-197.

Kipkorir, K., Raes, D. and Labadie, J. (2001). “Optimal allocation of short-term irrigation supply.” Irrig. and Drain. Systems, 15, 247-267.

Latif, M. and Sarwar, S. (1994). "Proposal for equitable water allocation for rotational irrigation in Pakistan.” Irrig. and Drain. Systems, 8, 35-48. 
Levine, G. and Coward, E.W. (1989). "Equity considerations in the modernisation of irrigation systems.” ODI-IIMI Irrigation Management Network Paper 89/2b.

Levite, H. and Sally, H. (2002). "Linkages between productivity and equitable allocation of water." Physics and Chemistry of the Earth (27):825-830.

Loftis, J. M. and Houghtalen, R. J. (1987). “Optimizing temporal water allocation by irrigation ditch companies.) Trans. ASAE, 30(4), 1075-1082.

Mainuddin, M., Gupta, A.D. and Onta, P.R. (1996). “Optimal crop planning model for an existing groundwater irrigation project in Thailand." Agricultural Water Management, 33, 43-62.

Malhotra, S.P. 1982. The Warabandi System and its Infrastructure. Central Board of Irrigation and Power, New Delhi, India.

Mandavi, A.B. 1998. Modernization of irrigation system operational management by way of canal automation in India. Modernization of irrigation system operations: Proceedings of the 5th ITIS network international meeting, Aurangabad, 28-30 October 1998 the Food and Agriculture Organization of the United Nations, Regional Office for Asia and the Pacific, Maliwan Mansion, 39 Phra Athit Road Bangkok 10200, Thailand. Mannocchi, F. and Mecarelli, P. (1994) "Optimization analysis of deficit irrigation systems.” J. Irrig. and Drain. Engrg., ASCE, 120(3), 484-503.

Matanga, G. B. and Marino, M. A. (1979). "Irrigation planning 1. Cropping pattern." Water Resour. Res., 15(3), 672-678.

Molden, D.J. and Gates, T.K. (1990). "Performance measures for evaluation of irrigation water delivery systems. J. Irrig. and Drain. Engrg., ASCE, 116(6):804-823.

Onta, P. R., Loof, R. and Banskota, M. (1995). "Performance based irrigation planning under water shortage.” Irrigation and Drainage Systems, 9, 143-162.

Paul, S., Panda, S.N. and Nagesh Kumar, D. (2000) "Optimal irrigation allocation: A multilevel approach.” J. Irrig. and Drain. Engrg., ASCE, 126(3), 149-156. 
Rao, N. H., Sarma P. B. S. and Chander, S. (1990). "Optimal multicrop allocation of seasonal and intraseasonal irrigation water." Water Resour. Res., 26(4), 551-559.

Sahoo, G.B., Loof, R., Abernethy, C.L. and Kazama, S. (2001). Reservoir release policy for large irrigation system. J. Irrig. and Drain. Engrg., ASCE, 127(5), 302-310.

Sampath, ’R.K. (1988). "Equity measures for irrigation performance evaluation.” Water International, 13, 25-32.

Shyam, R., Chauhan, H. S. and Sharma, J. S. (1994). "Optimal operation scheduling model for a canal system.” Agricultural Water Management 26, 213-225.

Small, L.S. and Rimal, A. (1996). "Effects of alternative water distribution rules on irrigation system performance: a simulation analysis." Irrig. and Drain. Systems, 10, $25-45$.

Smout, I.K. and Gorantiwar, S.D. (2005). "A multilevel approach for optimizing land and water resources and irrigation deliveries for tertiary units in large irrigation schemes: 1.method.” J. Irrig. and Drain. Engrg., ASCE, 131(3):254-263.

Smout, I.K., Gorantiwar, S.D. and Vairavamoorthy, K. (2005). "Performance based land and water allocation within irrigation schemes: 2. Application." J. Irrig. and Drain. Engrg., ASCE (In print).

Sritharan, S. I., Clyma, W. and Richardson, E. V. (1998). "On-farm application system design and project-scale water management." J. Irrig. and Drain. Engrg., ASCE, $114(4), 622-643$

Steiner, R.A. and Walter, M.F. (1992). "The effect of allocation and scheduling rules on equity and productivity in irrigation systems." Agricultural Water Management, 21, 297-312.

Sunantara, J.D. and Ramirez, J.A. (1997). “Optimal stochastic multicrop seasonal and intraseasonal irrigation control.” J. Water Resour. Plng. And Mgmt., ASCE, 123(1), 3948. 
Unal, H.B., Asik, S., Avci, M, Yasar, S. and Akkuzu, E. (2004). "Performance of water delivery system at tertiary canal level: a case study of the Menemen Left Bank Irrigation System, Gendiz Basin, Turkey. Agricultural Water Management, 65, 155-171.

Vedula S., and Mujumdar, P. P. (1992). "Optimal reservoir operation for irrigation of multiple crops.” Water Resour. Res., 28(1), 1-9.

Wardlaw, R. and Barnes, J. (1996). "Real time operation and management of irrigation systems." Proceedings of International Conference on New Challenges for civil Engineers of Developing Countries in the $21^{\text {st }}$ Century (NCCDC-96), ISEM, Civil Engg. Deptt., J.M.I., New Delhi, India, Feb. 29 to Mar. 2, 1996, 25-33.

Wardlaw, R. and Barnes, J. (1999) "Optimal allocation of irrigation water supplies in real time.” J. Irrig. and Drain. Engrg., ASCE, 1125(6), 345-354.

Yaron, D. and Dinar, A. (1982). "Optimum allocation of farm irrigation water during peak seasons.” Am. J. Agr. Economics, 64 (November), 681-689. 
Captions of figures (figures are arranged in order)

Fig. 1. Inclusion of optimization of productivity and equity in allocation process

Fig. 2. Area and Water Allocation Model (AWAM)

Fig. 3. The base for equity and means targeted for achieving equity 


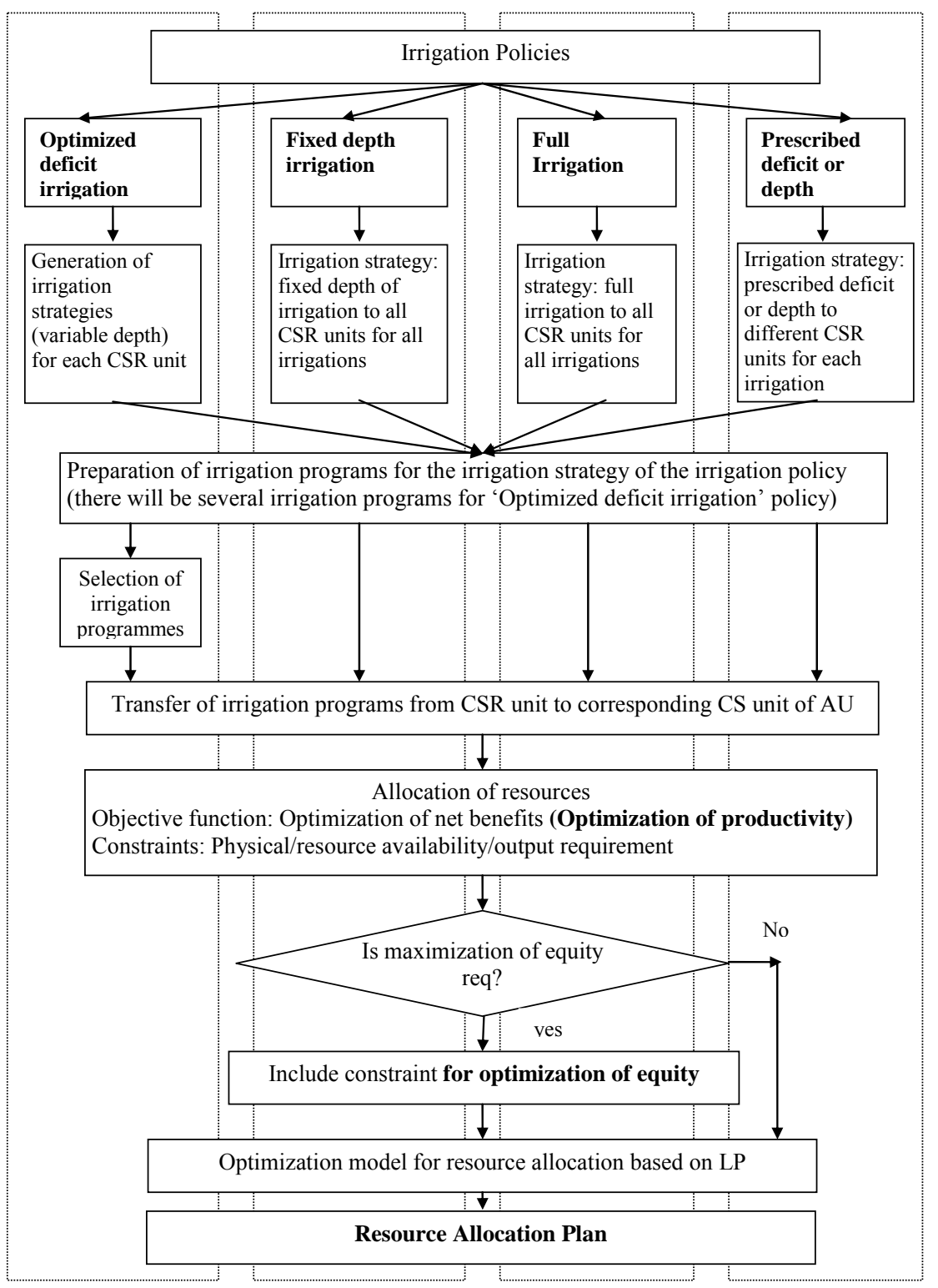




\begin{tabular}{|c|}
\hline $\begin{array}{l}\text { Phase: } 1 \\
\text { Selection of Irrigation Policy from: } \\
\text { 1.Optimised deficit irrigation } \\
\text { 2. Full irrigation } \\
\text { 3. Fixed depth irrigation } \\
\text { 4. Prescribed deficit or fixed depth for each Crop-Soil-Region (CSR) unit } \\
\text { Generation of irrigation strategies if the selected irrigation policy is } \\
\text { 'Optimized deficit irrigation' }\end{array}$ \\
\hline $\begin{array}{l}\text { Phase: } 2 \\
\text { Preparation of Irrigation Programs: } \\
\text { (consisting of information on expected yield/benefits and irrigation } \\
\text { requirement per irrigation for each irrigation strategy for each CSR unit) } \\
\text { with simulation model (SWAB-CRYB) for the specified irrigation policy } \\
\text { (and for each irrigation strategy of 'Optimized deficit irrigation' policy) }\end{array}$ \\
\hline $\begin{array}{l}\text { Phase: } \mathbf{3} \\
\text { Selection of irrigation programs (for 'Optimized deficit irrigation' policy } \\
\text { only) : } \\
\text { Selection of optimal and efficient irrigation programs from the irrigation } \\
\text { programs prepared at Phase: } 2 \text { for each CSR unit }\end{array}$ \\
\hline $\begin{array}{l}\text { Phase: } 4 \\
\text { Optimum allocation of resources: }\end{array}$ \\
\hline $\begin{array}{l}\text { Stage 1: Transfer of irrigation programs for each crop-soil (CS) unit of } \\
\text { allocation unit (AU) by modifying the irrigation programs of the } \\
\text { corresponding CSR unit developed in Phase:3, with consideration to } \\
\text { distribution and conveyance efficiencies. }\end{array}$ \\
\hline $\begin{array}{l}\text { Stage 2: Allocation of the resources to each CS unit of AU with certain } \\
\text { objectives and constraints with the optimization model (RA) } \\
\text { - Objective: Max. of net benefits/area/crop production } \\
\text { - Constraints: } 1 \text {. Physical, resource availability and output } \\
\text { requirement constraints } \\
\text { 2. Equity constraints for equity maximization }\end{array}$ \\
\hline 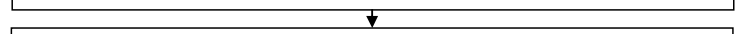 \\
\hline Stage 3: Preparation of water release schedule \\
\hline
\end{tabular}




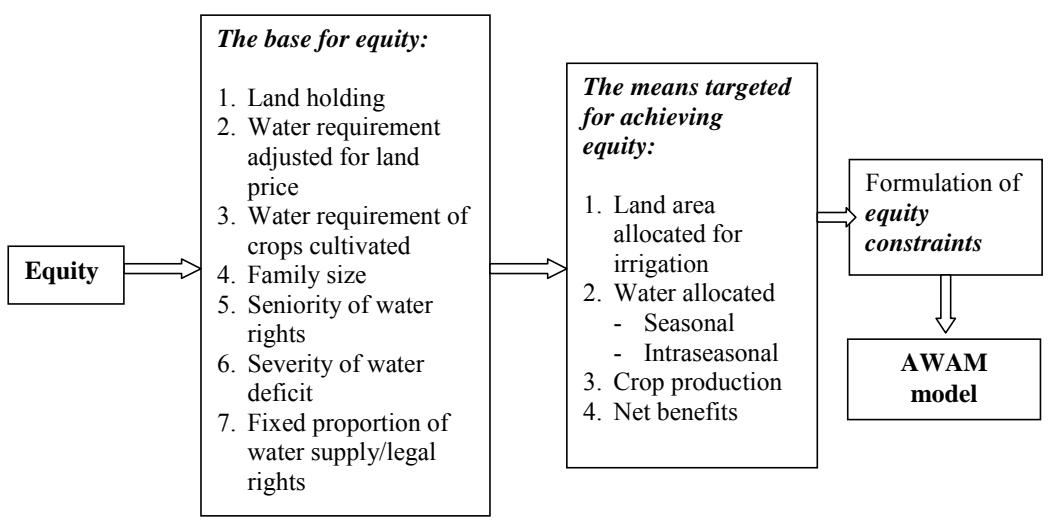

